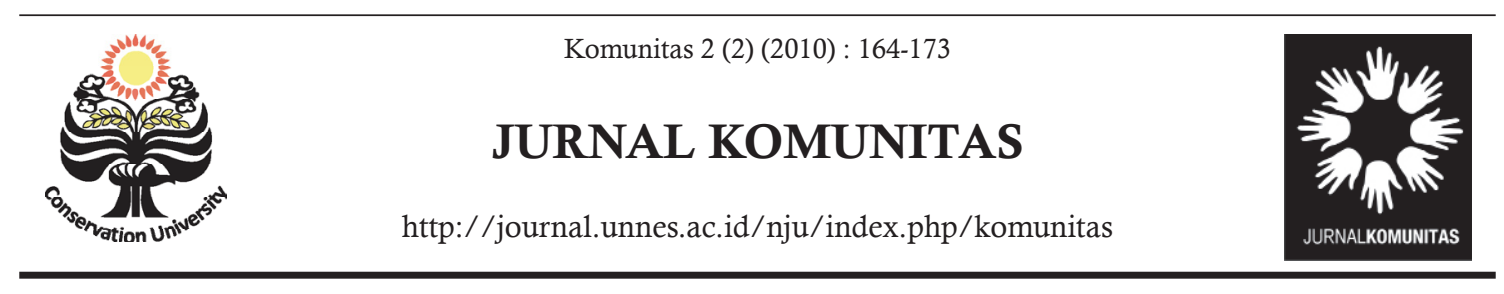

\title{
PENGEMBANGAN PEMBELAJARAN INKUIRI SOSIAL PADA MATERI INTERAKSI SOSIAL MATA PELAJARAN SOSIOLOGI
}

\author{
Andri Wirawan ${ }^{凶}$ \\ Universitas Wahid Hasyim Semarang, Indonesia
}

\section{Info Artikel}

Sejarah Artikel:

Diterima Juni 2010

Disetujui Juli 2010

Dipublikasikan September 2010

Keywords:

Social inquiry;

Social interaction;

School sociology.

\begin{abstract}
Abstrak
Tujuan penelitian ini adalah mendeskripsikan bagaimana pelaksanaan pembelajaran inkuiri di SMA Wahid Hasyim Tersono. Apa saja kendala dalam pengembanganpembelajaran inkuiri sosial tersebut dan bagaimana upaya mengatasi kendala dalam pengembanganpembelajaran inkuiri disekolah tersebut? Hasil penelitian menunjukkan bahwa pelaksanaan pembelajaran inkuiri sosial di SMA Wahid Hasyim Tersono sangat mempengaruhi sistem pembelajaran siswa di sekolah. Siswa dapat menemukan hal-hal yang baru yang terjadi dalam interaksi sosial seperti hubungan antar siswa, siswa dengan guru atau dalam masyarakat sehingga dapat memberikan akibat siswa menjadi lebih aktif dalam pembelajaran maupun pergaulan sehari-hari. Kendala-kendala yang dihadapi antara lain siswa yang tidak setara SDMnya, guru yang sulit menyetarakan masalah dengan materi dan keterbatasan waktu, sarana prasarana yang kurang kondusif dalam proses pembelajaran.
\end{abstract}

\begin{abstract}
The purpose of this study is to describe the implementation of inquiry learning in Wahid Hashim Tersono High School. What are the obstacles in the development of social inquiry learning and what efforts are used to overcome the obstacles in the development of inquiry learning? The results shows that the implementation of social inquiry learning in school Wahid Hashim Tersono shapes student's creativity in the school. Students can discover new things that are happening in social interactions such as the relationship between students, between studentsand teacher, and students with the community. It can be said that the method helps students become more active in learning and daily life. The constraints of the methodinclude the different level of students' capacity, a teacher difficult to equate with material issues and time constraints, and a lack of infrastructure conducive to the learning process.
\end{abstract}

(C) 2010 Universitas Negeri Semarang 


\section{PENDAHULUAN}

Salah satu model pembelajaran yang inovatif adalah metode inkuiri. Costa (1985), Mallinson (1991), Joyce dan Weil (1992), Silberman (1996), Slavin (1997), serta Gulo (2002) menyatakan bahwa inkuiri tidak hanya mengembangkan kemampuan intelektual tetapi seluruh potensi yang ada termasuk pengembangan emosional dan ketrampilan inkuiri merupakan suatu proses yang bermula dari merumuskan masalah, merumuskan hipotesis, mengumpulkan data, menganalisis data, dan membuat kesimpulan.

Salah satu materi dalam mata pelajaran Sosiologi yang menuntut adanya kerja kelompok adalah interaksi sosial. Penelitian ini akan menggunakan metode inkuiri sosial pada materi interaksi sosial mata pelajaran Sosiologi di kelas $\mathrm{X}$ yang akan dilakukan di SMA Wahid Hasyim Tersono Kecamatan Tersono Kabupaten Batang dan dipilihlah kelas X1 sebagai subjek dan objek penelitian karena berdasarkan wawancara dengan guru mata pelajaran Sosiologi SMA Wahid Hasim Tersono kelas X1 lebih mudah untuk dikondisikan sehingga akan mempermudah pelaksaaan dalam penelitian.

Pertanyaan dalam penelitian ini adalah bagaimana pelaksanaan pembelajaran inkuiri sosial pada materi interaksi sosial mata pelajaran Sosiologi kelas $\mathrm{X}_{1}$ SMA Wahid Hasyim Tersono Kabupaten Batang ? Apa saja kendala dan bagaimana upaya mengatasi kendala dalam pengembangan pembelajaran inkuiri sosial pada materi interaksi sosial mata pelajaran Sosiologi di SMA Wahid Hasyim Tersono Kabupaten Batang?

Dalam penelitiannya Luailik Nikmatul (2010) menyimpulkan bahwa metode inkuiri berhasil meningkatkan minat siswa dan guru dalam pembelajaran PKn di kelas III SDN Petung I Kecamatan Pasrepan Pasuruan dengan materi pokok Peraturan di Masyarakat. Hal ini dibuktikan dengan meningkatnya keterampilan guru dan hasil belajar siswa aspek kognitif dan aspek afektif. Dan disarankan pada guru agar pada pembelajaran $\mathrm{PKn}$ hendaknya menggunakan metode inkuiri sosial pada khususnya dan menyesuaikan dengan materi yang akan disampaikan, sehingga dapat meningkatkan hasil belajar siswa. Hendaknya kepala sekolah memberi informasi atau bimbingan khusus mengenai inovasi pembelajaran kepada para guru dalam upaya peningkatan kualitas pendidikan di SD. Kesadaran siswa terhadap proses inkuiri dapat ditingkatkan, sehingga mereka dapat diajarkan prosedur pemecahan masalah secara ilmiah. Adapun pelaksanaanya adalah sebagai berikut:

Guru membagi tugas meneliti sesuatu masalah ke kelas. Siswa dibagi menjadi beberapa kelompok, dan masing-masing kelompak mendapat tugas tertentu yang dikerjakan. Kemudian mereka mempelajari, meneliti dan membahas tuganya di dalam kelompok didiskusikan, kemudian dibuat laporan yang tersusun dengan baik. Akhirnya hasil laporan kerja kelompok dilaporkan ke sidang pleno, dan terjadinya diskusi secara luas. Dari sidang plenolah kesimpulan akan dirumuskan sebagai kelanjutan hasil kerja kelompok. Dan kesimpulan yang terakhir bila masih ada tindak lanjut yang harus dilaksanakan (Roestiyah, 2008: 75-76).

Dalam inkuiri, diajarkan pada siswa bahwa segala pengetahuan itu bersifat sementara dan dapat berubah dengan munculnya teori-teori baru. Oleh karena itu, siswa harus disadarkan bahwa pendapat orang lain dapat memperkaya pengetahuan yang dimiliki (Richard Suchman dalam Wena, 2009:76). Secara umum prinsip strategi inkuiri ini sebagai berikut : Siswa akan bertanya jika mereka dihadapkan pada masalah yang membingungkan/ kurang jelas. Siswa dapat menyadari dan belajar menganalisis strategi berpikir mereka. Strategi berpikir baru dapat diajarkan secara langsung dan ditambahkan pada apa yang telah mereka miliki. Inkuiri dalam kelompok dapat memperkaya khasanah pikiran dan membantu siswa belajar mengenai sifat pengetahuan yang sementara dan menghargai pendapat orang lain.

Model inkuiri tercipta melalui konfrontasi intelektual, di mana siswa dihadapkan pada suatu situasi yang aneh dan mereka mulai bertanya-tanya tentang 
hal tersebut. Dikarenakan tujuan akhir ini adalah pembentukan pengetahuan yang baru, maka siswa dihadapkan pada suatu yang memungkinkan untuk diselidiki dengan lebih cermat (Joice and Weil dalam Wena, 2009:76). Setelah situasi tersebut disajikan kepada siswa, kepada mereka diajarkan bahwa pertama-tama mereka perlu mengupas beberapa aspek dari situasi ini, misalnya sifat dan identitas obyek serta kejadian yang berhubungan dengan situasi tersebut.

Strategi inkuiri merupakan strategi pembelajaran yang dasar filosofinya konstruktivisme karena melalui strategi ini, siswa membangun sendiri pengetahuannya. Dalam strategi inkuiri, siswa dilatih memecahkan masalah akademik, meningkatkan pemahaman terhadap sains, mengembangkan keterampilan belajar sains, dan literasi sains (Keefer, 1998; German, 1991; Oates, 2002). Lawson (2000) mengemukakan kegiatan inkuiri dapat melatih kecakapan berpikir siswa dan meningkatkan kererampilannya dalam memecahkan masalah.

Indrawati (1999) dalam Trianto (2007:134) menyatakan bahwa suatu pembelajaran pada umumnya akan lebih efektif bila dilaksanakan melalui modelmodel pembelajaran yang termasuk rumpun pemprosesaninformasi. Halinikarena modelmodel pemprosesan informasi menekankan pada bagaimana seseorang berpikir dan bagaimana dampaknya terhadap cara-cara mengolah informasi. Salah satu satu model pembelajaran pemprosesan informasi adalah inkuiri.

Strategi inkuiri berarti suatu rangkaian kegiatan belajar yang melibatkan secara maksimal seluruh kemampuan siswa untuk mencari dan menyelidiki secara sistematis, kritis, logis, adan analitis sehingga mereka dapat merumuskan sendiri penemuannya dengan penuh percaya diri. Sasaran utama pembelajran inkuiri adalah (1) keterlibatan siswa secara maksimal dalam proses pembelajaran, (2) keterarahan kegiatan secara logis dan sistematis pada tujuan pembelajaran, dan (3) mengembangkan sikap percaya pada diri siswa tentang apa yang ditemukan dalam proses inkuiri.

Strategi pembelajaran inkuiri sosial (social science inquiry) dikembangkan oleh Massialas \& Cox (1966) untuk memecahkan masalah dalam pembelajaran sosial. Strategi pembelajaran inkuiri sosial terdiri dari enam tahap pembelajaran yaitu :

Orientasi. Tahap orientasi merupakan tahap awal dimana dalma tahap ini guru harus mampu membangun/mengembangkan rasa peka terhadap masalah-masalah sosial atas objek yang dibahas. Kepekaan siswa mungkin akan muncul/tumbuh dari pengamatan situasi kehidupan sehari-hari, dari hasil refleksi terhadap suatu bacaan/ topik, dari situasi konflik yang ada di kelas atau sejumlah sumber lain (Wena, 2009:82).

Hipotesis. Tahap kedua pengembangan hipotesissejelas mungkin sebagaikonsekuensi dari permasalahan yang sedang dikaji. Hipotesis yang diajukan dapat dijadikan penntun pada proses inkuiris elanjutnya dengan siswa berusaha memverifikasi komponen-komponen masalah yang sedang dipecahkan (Wena, 2009:82)

Definisi Dalam. Tahap ini hipotesis yang diajukan diklarifikasi dan didefinisikan sehingga semua kelompok siswa dapat memahami dan mengkomunikasikan permasalahan yang dibahas. Untuk tahap ini pendefinisian suatu konsep/teori harus menggunakan bahasa yang jelas dan mudah dipahami oleh siswa (Joice \& Well dalam Wena, 2009:83).

Eksplorasi. Dalam tahap ini hipotesis yang diajukan diperluas/dianalisis, implikasinya asumsi-asumsinya, dan deduksi yang mungkin dilakukan dari hipotesis tersebut. Dalam hal ini dilakukan kajian terhadap kualitas dan kekurangan hipotesis, yang diuji tingkat validitas logisnya dan konsistensi internalnya. Seperti diungkapkan Wilen \& Clegg (1996) salah satu tujuan pembelajaran ilmu sosial adalah menumbuhkembangkan pengetahuan dan keterampilan siswa dalam melakukan eksplorasi terhadap gejala-gejala sosial yang multikompleks (Wena, 2009:83).

Pembuktian. Pada tahap ini fakta dan bukti yang dibutuhkan untuk mendukung hipotesis dikumpulkan, sesuai dengan 
karakteristik hipotesis yang diajukan. Dalam tahap ini siswa dibimbing cara-cara mengumpulkan bukti, fakta, data yang berhubungan dengan hipotesis yang diajukan. Siswa didorong belajar memverifikasi, mengklasifikasi, dan mereduksi data-data (Wena, 2009:83).

Generalisasi. Tahap akhir dari strategi ini adalah pengungkapan penyelesaian masalah yang dipecahkan. Dari data-data (bukti, fakta) yang telah dikumpulkan dan dianalisis, siswa didorong untuk mencoba mengembangkan beberapa kesimpulan, dan dari berbagai kesimpulan yang telah dibuat, siswa diajar bagaimana memilih pemecahan masalah yang paling tepat (Wena, 2009:83).

Strategi pembelajaran inkuiri sosial telah banyak diterapkan dalam pembelajaran dan terbukti dapat meningkatkan hasil belajar siswa. Uji coba penerapan inkuiri ini dilakukan Massialas \& Cox (1966) dalam Made Wena (2009:86) pada mata pelajaran ilmu sosial di sekolah menengah, menunjukkan bahwa hampir $80 \%$ siswa mengalami peningkatan hasil belajar dan kemampuan memecahkan masalah-masalah sosial secara signifikan.

Penelitian yang dilakukan pada siswa kelas 11 jurusan IPS di Los Angeles USA menunjukkan bahwa penerapan strategi pembelajaran inkuiri sosial secara signifikan dapat meningkatkan kemampuan pemecahan masalah siswa (Joice and Weil, 1992) dalam Made Wena (2009:87).

Menurut Beyer (1995) dalam Wena (2009:87) proses pembelajaran dengan strategi pembelajaran inkuiri sosial, secara bertahap dapat meningkatkan kemampuan kritis siswa terhadap suatu masalah yang dipecahkan. Namun, menurut Hunkins (1996) dalam Wena (2009:87) strategi pembelajaran inkuiri sosial bisa efektif dilaksanakan jika pengajar mampu menyiapkan bahan ajar yang

\section{METODE PENELITIAN}

Metode penelitian yang digunakan adalah metode deskriptif kualitatif. Peneliti menggunakan metode wawancara dan observasi. Dalam penelitian ini peneliti mendapatkan subjek penelitian sebanyak 8 orang, 7 orang sebagai informan utama dan 1 orang sebagai informan kunci. Sebanyak 7 orang yang diteliti adalah siswa yang terlibat dalam pembelajaran inkuiri sosial pada materi interaksi sosial di kelas X. Ketujuh orang subjek yang dipilih sebagai informan adalah siswa kelas $\mathrm{X}$, sedangkan 1 orang adalah guru mata pelajaran Sosiologi yang sekaligus sebagai Wakil Kepala Sekolah bidang Kesiswaan. Dari hasil penelitian yang dilakukan, diperoleh gambaran mengenai karakteristik subjek penelitian yang meliputi: nama, usia, pendidikan terakhir, dan pekerjaan.

\section{HASIL DAN PEMBAHASAN}

SMA Wahid Hasyim Tersono merupakan lembaga pendidikan formal yang berdiri sejak tahun 1990 denga izin dari Departemen Pendidikan Nasional tanggal 15 Pebruari 1990. SMA Wahid Hasyim Tersono berlokasi di Jalan Lapangan Gedongsari Tersono Kecamatan Tersono Kabupaten Batang. SMA Wahid Hasyim Tersono merupakan sekolah swasta yang didirikan oleh Yayasan Al-Ma'arif dengan waktu penyelenggaraan pagi hari. SMA Wahid Hasyim Tersono memiliki guru sebanyak 24 orang. (terlampir) dan karyawan staf administrasi 6 orang. Jumlah siswa SMA Wahid Hasyim Tersono tahun ajaran 2009/2010 sebanyak 214 siswa.

Dari data penelitian dapat diambil kesimpulan bahwa pelaksanaan pembelajaran inkuiri sosial pada materi interaksi sosial mata pelajaran Sosiologi kelas $\mathrm{X}_{1}$ SMA Wahid Hasyim Tersono Kabupaten Batang sebagai berikut:

Pertama, tahap penyajian masalah. Pada tahapan ini, siswa didorong untuk mencari contoh kasus sosial yang ada dikehidupan masyarakat, dalam tahap ini siswa dirangsang aktivitas intelektualnya kemudian siswa merasa dirinya berada ditengah-tengah sosialis kemasyarakatan.

Kedua, tahap pengumpulan data verifikasi. Guru merangsang siswa untuk aktif memberikan contoh-contoh kasus yang sesuai dengan materi kemudian diambil 
beberapa kasus sosial yang disetujui bersama untuk didiskusikan kemasing-masing kelompok yang terdiri dari 4-5 siswa.

Ketiga, tahap pengumpulan data eksperimentasi. Setelah perkelompok mendapat kesempatan berdiskusi maka setiap kelompok harus mempersentasikan hasilnypa dan sesi tanya jawab dapat berlangsung. Setiap kelompok harus menyimak semua hasil diskusi yang telah berlangsung, ini mendorong siswa untuk berargumen dan mampu mengikuti jalannya diskusi juga dapat mendapatkan informasi baru untuk menambah wawasan

Keempat, tahap organisasi data dan formasi kesimpulan. Kesimpulan yang harus diambil berupa hasil diskusi, setiap kelompok harus bisa menyimpulkan hasil paparan kelompoknya sendiri dan juga kelompok yang lain, guna mendorong siswa agar mampu mengikuti diskusi dan menambah wawasan.

Kelima, tahap analisis proses inkuiri. Setelah semua berjalan sesuai tahapan maka siswa merangkum semua hasil diskusi dan memberikan hasil diskusinya kepada guru

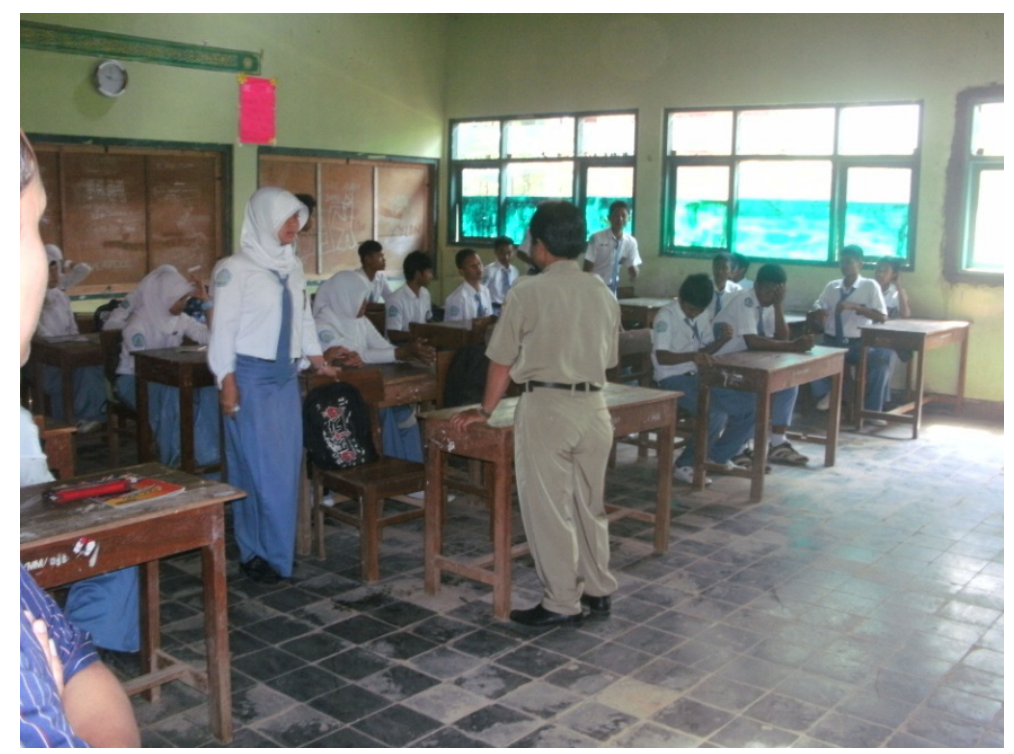

Sumber : Hasil Penelitian, 2010, Andri Wirawan

Gambar 1. Guru Mengkondisikan Siswa Untuk Diskusi

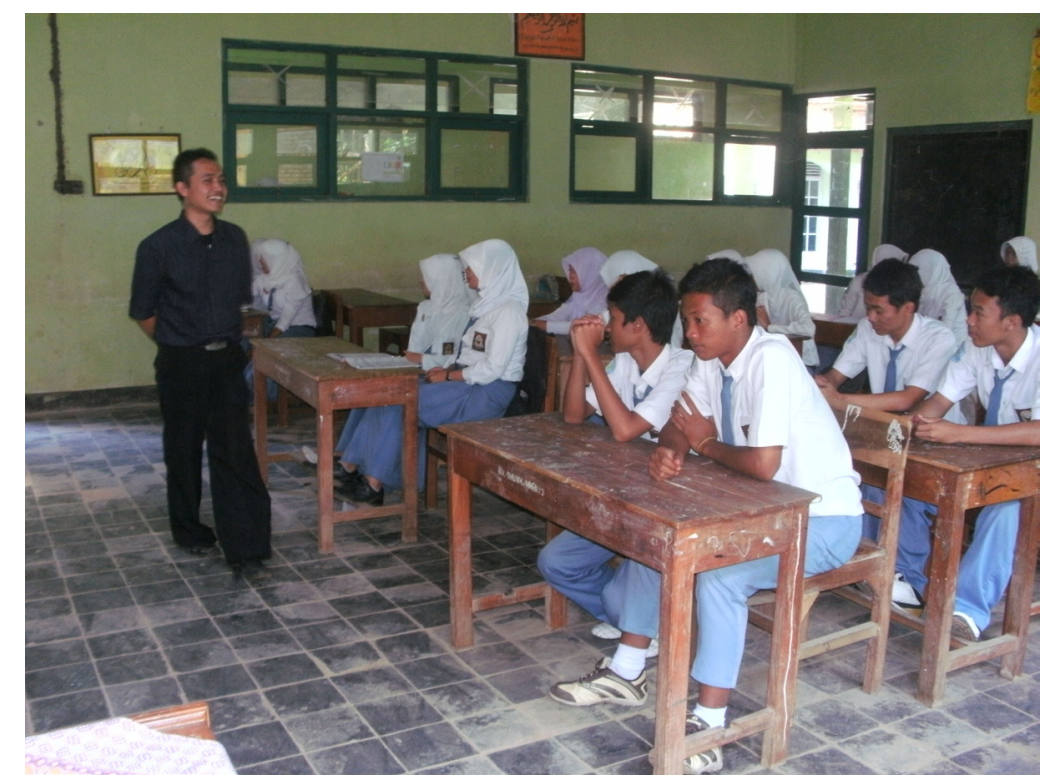

Gambar 2. Suasana belajar di kelas 
yang mengikuti diskusi, siswa didorong untuk menilai hasil pertanyaan atau kritik yang membangun dan kemudian guru memberikan jawaban dari pertanyaanpertanyaan yang membangun dan diharapkan mampu memuaskan pertanyaan siswa.

Pengalaman di sekolah ini menunjukkan metode inkuiri sosial sesuai atau cocok digunakan untuk pembelajaran Sosiologi pada materi interaksi sosial karena siswa dapat menemukan hal-hal yang baru yang terjadi dalam interaksi sosial seperti hubungan antar siswa, siswa dengan guru atau dalam masyarakat sehingga dapat memberikan akibat siswa menjadi lebih aktif dalam pembelajaran maupun pergaulan sehari-hari.

Penerapan metode inkuiri sosial dilakukan didalam dan diluar kelas, didalam kelas siswa diberi motivasi dan dipancing keaktifan siswa dengan cara memberikan tugas berbicara didepan kelas atau diskusi, dan juga bisa dilakukan diluar kelas dengan cara praktek berinteraksi dengan sesama siswa atau siswa dengan masyarakat. Tahap-tahap pembelajaran dengan metode inkuiri sosial pada materi interaksi sosial adalah: siswa memperoleh pengetahuan tentang interaksi sosial didalam kelas dan diharapkan mampu membaca peristiwa interaksi sosial dalam kehidupan sehari-hari yang mencakup kontak sosial dan komunikasi. (Wawancara dengan Bapak Nur Khozin, 2 Februari 2010)

Berdasarkan hasil wawancara dapat diketahui bahwa metode inkuiri sosial dilakukan di dalam dan di luar kelas, di dalam kelas siswa diberi motivasi dan dipancing keaktifan siswa dengan cara memberikan tugas berbicara didepan kelas atau diskusi, juga bisa dilakukan diluar kelas dengan cara praktek berinteraksi dengan sesama siswa atau siswa dengan masyarakat.

Dalam sebuah pembelajaran, tentu dimulai dari kegiatan awal, pelaksanaan dan evaluasi. Demikian pula pada saat pembelajaran menggunakan metode inkuiri sosial apakah guru merumuskan tujuan setiap proses pembelajaran. Hal ini seperti dijelaskan oleh Bapak Nur Khozin kepada peneliti.

Ya, kalau perumusan kegiatan, tujuan pembelajaran jelas tertuang dalam RPP karena setiap guru pasti mengetahui dan dapat membuat RPP. Walaupun kadang antara RPP dengan praktek di lapangan berbeda, tetapi guru tetap berpegang pada RPP atau rencana pembelajaran dalam menjalankan perannya sebagai seorang fasilitator. (Wawancara dengan Bapak Nur Khozin, 2 Februari 2010).

Berdasarkan hasil wawancara di atas ketika ditanyakan, apakah guru merumuskan tujuan setiap proses pembelajaran? Pak Khozin menjelaskan bahwa guru sebagai pelaksana kurikulum dan pengajar maupun fasilitator pembelajaran dituangkan dalam RPP yang memuat standar kompetensi, kompetensi dasar, tujuan pembelajaran serta indikator keberhasilan.

Dalam merumuskan indikator keberhasilan juga ditanyakan apa saja indikator keberhasilan siswa dalam pembelajaran mata pelajaran Sosiologi pada materi interaksi sosial seperti dijelaskan Pak Khozin kepada peneliti.

$$
\begin{aligned}
& \text { Indikator keberhasilan yang } \\
& \text { dicapai dalam pembelajaran adalah } \\
& \text { pemahaman materi, baik secara } \\
& \text { kognitif, afektif maupun psikomotor } \\
& \text { dengan penilaian praktek langsung } \\
& \text { dalam interaksi sosial yang terjadi } \\
& \text { diantara siswa, siswa dengan guru dan } \\
& \text { sebagainya. }
\end{aligned}
$$

.Ketika ditanyakan tentang apakah guru merencanakan penilaian siswa dan bagaimana caranya dijelaskan Pak Khozin sebagai berikut.

Penilaian siswa telah tertuang dalam rencana pembelajaran (RPP) 
yang disesuaikan dengan alokasi waktu yang tersedia. Dalam KTSP telah dijelaskan bahwa penilaian tidak hanya berdasarkan hasil tes tertulis saja, tetapi juga berasal dari penilaian proses selama kegiatan pembelajaran berlangsung, seperti antusias siswa, tingkat keaktifan siswa, kerja kelompok, dan sikap selama proses pembelajaran sehingga pada akhirnya setiap siswa akan memperoleh nilai yang objektif. (Wawancara dengan Bapak Nur Khozin, 2 Februari 2010).

Permasalahan yang dikaji selanjutnya adalah bagaimana guru melakukan penilaian saat proses pembelajaran mengingat guru seorang diri dalam mempersiapkan materi, menyampaikan materi, mengelola kelas, dan menjaga kelangsungan proses belajar mengajar sekondusif mungkin, seperti diungkapkan oleh informan kepada peneliti.

Penilaian saat proses pembelajaran memang lebih sulit dibandingkan dengan penilaian dengan tes formatif atau ulangan harian karena guru berperan ganda dalam proses pembelajaran mulai dari mempersiapkan materi, menyiapkan media, menggunakan metode, mengelola kelas hingga melakukan penilaian kepada siswa. Tidak mungkin dalam satu waktu guru dapat menilai seluruh siswa selama proses pembelajaran berlangsung. Namun demikian dengan metode inkuiri sosial yaitu dengan $\mathrm{me} \mathrm{m} \mathrm{bu} \mathrm{at}$ kelompok-kelompok siswa, penilaian relatif lebih mudah dilakukan karena guru cukup mengamati kerja atau perkembangan dari masing-masing kelompok. (Wawancara dengan Bapak Nur Khozin, 2 Februari 2010).

Dalam pelaksanaan suatu metode pembelajaran disamping terdapat kelebihankelebihan tentu juga ada kelemahankelemahan yang dapat menjadi kendala yang dihadapi. Permasalahan yang dikaji setelah ini adalah apakah guru mengalami kesulitan saat menerapkan metode Inkuiri Sosial, mengapa hal ini dapat terjadi dapat diungkap dari hasil wawancara berikut.

Kesulitan yang dialami guru dalam pembelajaran menggunakan metode inkuiri adalah menyesuaikan masalah yang dimunculkan dalam pembelajaran dengan tujuan agar proses belajar mengajar tidak memberatkan siswa, siswa tidak merasa tertekan dalam proses pembelajaran saat siswa diberikan pengalaman baru dalam pembelajaran.

Selain dari guru ada pula kendala yang dihadapi dalam proses pembelajaran inkuiri yaitu dari murid, karena SDM antar siswa yang tidak sama menyebabkan proses pembelajaran yang menarik, ada yang sangat mudah menerima materi ada pula yang susah untuk mengerti, dan hal ini menjadi penghambat karena sedikit siswa yang aktif mengikuti pembelajaran.

Dari sarana dan prasaranapun ikut andil dalam proses penghambat pembelajaran inkuiri. Suatu hal yang disepelekan oleh sekolah, karena lab sosiologi ada di masyarakat maka sekolah kurang memfasilitasi dalam proses pembelajaran sehingga guru sosiologi harus pintar-pintar dalam menyampaikan materi yang disesuaikan dengan kondisi atau masalah-masalah sosial yang ada dimasyarakat, selain itu kendala yang lain adalah kurangnya sumber bacaan yang ada di perpustakaan yang menyebabkan siswa kurang pengetahuan, keadaan ruang kelas yang kurang kondusifpun menjadi sangat berpengaruh terhadap keberhasilan pembelajaran.

Strategi inkuiri merupakan strategi pembelajaran yang dasar filosofinya konstruktivisme karena, melalui strategi ini, siswa membangun sendiri pengetahuannya. Dalam strategi inkuiri, siswa dilatih memecahkan masalah akademik, meningkatkan pemahaman terhadap sains, dan mengembangkan keterampilan belajar sains (Keefer, 1998; German, 1991; Oates, 2002). Lawson (2000) mengemukakan kegiatan inkuiri dapat melatih kecakapan berpikir siswa dan meningkatkan 
kererampilannya dalam memecahkan masalah.

Indrawati (1999) dalam Trianto (2007:134) menyatakan bahwa suatu pembelajaran pada umumnya akan lebih efektif bila dilaksanakan melalui modelmodel pembelajaran yang termasuk rumpun pemprosesaninformasi. Halinikarena modelmodel pemprosesan informasi menekankan pada bagaimana seseorang berpikir dan bagaimana dampaknya terhadap cara-cara mengolah informasi. Salah satu satu model pembelajaran pemprosesan informasi adalah inkuiri.

Dalam materi interaksi sosial standar kompetensinya adalah Memahami perilaku keteraturan hidup sesuai dengan nilai dan norma yang berlaku dalam masyarakat. Kompetensi dasarnya adalah menjelaskan fungsi sosiologi sebagai ilmu yang mengkaji hubungan masyarakat dan lingkungan.

Pada materi ini indikator pencapaian kompetensi adalah (1) menjelaskan hubungan antara berbagai konsep realitas sosial budaya, (2) mendeskpripsikan hubungan berbagai konsep tentang realitas sosial dan (3) mengidentifikasi data tentang realitas sosial masyarakat.

Tujuan pengajaran sosiologi di sekolah menengah pada dasarnya mencakup dua sasaran yang bersifat kognitif dan bersifat praktis. Secara kognitif pengajaran Sosiologi dimaksudkan untuk memberikan pengetahuan dasar Sosiologi agar siswa mampu memahami dan menelaah secara rasional komponen-komponen dari individu, kebudayaan dan masyarakat sebagai suatu sistem. Sementara itu sasaran yang bersifat praktis dimaksudkan untuk mengembangkan keterampilan sikap dan perilaku siswa yang rasional dan kritis dalam menghadapi kemajemukan masyarakat, kebudayaan, situasi sosial serta berbagai masalah sosial yang ditemukan dalam kehidupan seharihari.

Berdasarkan hasil wawancara dan observasi yang dilakukan selama penelitian menunjukkan bahwa metode inkuiri sosial dapat digunakan dalam pembelajaran Sosiologi pada materi interaksi sosial siswa kelas X SMA Wahid Hasyim Tersono
Batang. Hal ini disebabkan karena metode inkuiri merupakan suatu rangkaian kegiatan belajar yang melibatkan secara maksimal seluruh kemampuan siswa untuk mencari dan menyelidiki secara sistematis, kritis, logis, dan analitis sehingga mereka dapat merumuskan sendiri penemuannya dengan penuh percaya diri.

Hal ini sesuai dengan teori yang dikemukakan oleh Soekanto (2007) bahwa interaksi sosial merupakan dasar proses sosial, yang menunjuk pada hubunganhubungan sosial yang dinamis. Untuk mempelajari interaksi sosialyang terjadi di masyarakat tidak cukup hanya dengan membaca atau mendengarkan saja materi pelajaran yang disampaikan oleh guru, namun siswa perlu mengalami sendiri atau praktek langsung agar siswa memperoleh pengetahuan, dan kemampuan dalam interaksi sosial atau kehidupan bermasyarakat nantinya. Penggunaan metode inkuiri sosial sangat cocok digunakan dalam pembelajaran Sosiologi materi interaksi sosial karena pembelajaran ilmu sosial adalah menumbuhkembangkan pengetahuan dan keterampilan siswa dalam melakukan eksplorasi terhadap gejala-gejala sosial yang multikompleks.

Adanya kendala-kendala yang dihadapi dalam pelaksanaan metode inkuiri sosial dalam pembelajaran Sosiologi pada materi Interaksi Sosial tidak membuat siswa atau guru bersikap apatis, statis, atau tidak mau mengikuti perubahan dan cepatnya perkembangan ilmu pengetahuan. Masalah, hambatan dan kendala akan senantiasa ada dalam penerapan suatu metode dan ini harus disikapi dengan arif, wajar, dan proporsional dengan harapan tujuan pembelajaran dan tujuan pendidikan dapat tercapai.

Dalam penelitian ini telah diperoleh informasi maupun fakta-fakta yang dapat digeneralisasikan. Namun generalisasi dari hasil penelitian ini belum tentu berlaku di tempat lain atau sekolah lain karena setiap individu dalam suatu kelompok dalam hal ini beberapa informan yang diteliti mempunyai tugas fungsional dan struktural yang berbeda antara informan yang satu dengan informan lainnya. Masing-masing individu (siswa) 
memiliki karakteristik yang berbeda dengan siswa di sekolah lain sehingga generalisasi dari hasil penelitian ini terbatas pada informasi dimana penelitian ini dilakukan sehingga penerapan pada ruang lingkup yang lebih luas dengan karakteristik berbeda kiranya perlu dilakukan penelitian lagi karena karakteristik berbeda akan menghasilkan keragaman yang berbeda pula.

Dari kendala yang dialami guru yaitu sulitnya menyesuaikan masalah maka upaya untuk mengatasinya adalah Guru seharusnya lebih kerja keras untuk meningkatkan pembelajaran, melalui kegiatan MGMP dan sertifikasi diharapkan mampu meningkatkan pengetahuan dan wawasan yang dapat meningkatkan mutu kompetensi guru. Sesuai dengan keadaan siswa yang tidak setara SDMnya maka pemecahan masalahnya yaitu siswa diharakan lebih aktif dan terjalin kerja sama yang positif antar siswa, dengan demikian mutu pembelajaran akan lebih baik dan mudahnya menerapkan metode pembelajaran dalam materi apapun. Seperti yang tertuang dalam tujuan sekolah bahwa prasarana dan sarana harus dilengkapi maka untuk menunjang pembelajaran harus disesuaikan dengan kemampuan sekolah, untuk itu diharapkan sarana dan prasarana dapat terlengkapi agar pembelajaran dapat tercipta yang lebih baik.

\section{SIMPULAN}

Berdasarkan hasil penelitian dan pembahasan tentang pembelajaran inkuiri sosial pada materi interaksi sosial mata pelajaran sosiologi kelas $\mathrm{x}_{1}$ di SMA Wahid Hasyim Tersono dapat disimpulkan sebagai berikut. Pelaksanaan pembelajaran inkuiri sosial pada materi interaksi sosial mata pelajaran Sosiologi kelas $\mathrm{X}_{1}$ SMA Wahid Hasyim Tersono Kabupaten Batang sangat mempengaruhi sistem pembelajaran siswa di sekolah karena siswa dapat menemukan halhal yang baru yang terjadi dalam interaksi sosial seperti hubungan antar siswa, siswa dengan guru atau dalam masyarakat sehingga dapat memberikan akibat siswa menjadi lebih aktif dalam pembelajaran maupun pergaulan sehari-hari.
Kendala-kendala yang dihadapi dalam proses pembelajaran inkuiri adalah dari beberapa faktor yaitu siswa yang tidak setara SDMnya, guru yang sulit menyetarakan masalah dengan materi dan keterbatasan waktu, sarana prasarana yang kurang kondusif dalam proses pembelajaran. Upaya mengembangkan pembelajaran inkuiri Sosial pelajaran Sosiologi kelas X1 SMA Wahid Hasyim Tersono yaitu dari guru seharusnya lebih meningkatkan pembelajaran dengan menerapkan strategi-strategi pembelajaran yang menunjang proses pembelajaran, dari siswa seharusnya lebih aktif dan meningkatkan kerjasama agar tercipta pembelajaran yang harmonis, semua itu juga harus didukung oleh sarana dan prasarana yang kondusif agar dapat meningkatkan pembelajaran.

\section{DAFTAR PUSTAKA}

Arikunto, S . 2006. Prosedur Penelitian Suatu Pendekatan Praktek. Jakarta : Rineka Cipta.

Depdiknas. 2003. Standar Kompetensi Mata Pelajaran Sosiologi SMA/MA. Jakarta : Depdiknas.

Dwi Narjoko, J, Suyanto, B .2004. Sosiologi Teks Pengantar Dan Terapan. Jakarta : Kencana Prenada Media Group

Hamalik, O . 2009. Proses Belajar Mengajar. Jakarta : Bumi Aksara.

Miles dan Huberman. 1999. Metode Kualitatif terjemahan Rachman. Semarang : Unnes.

Moleong, LJ. 2001. Metode Penelitian Kualitatif. Bandung: Remaja Rosdakarya.

Mulyasa, E. 2006. Kurikulum Tingkat Satuan Pendidikan. Bandung : PT Remaja Rosdakarya.

Philipus, Ng, Aini, N . 2004. Sosiologi Dan Politik. Jakarta : PT Rajagrafindo Persada

Roestiyah, N.K.2008. Strategi Belajar Mengajar. Jakarta : Rineka Cipta

Soekanto, S . 2007. Sosiologi Suatu Pengantar. Jakarta : Erlangga.

Sugiyono. 2009. Metode Penelitian Kuantitatif, Kualitatif, $R \& D$. Bandung: Alfabeta.

Trianto, 2007. Model-Model Pembelajaran Inovatif Berorientasi Konstruktivistik. Jakarta : Prestasi Pustaka.

Triarso, A . 2004. Dasar-dasar Instruksional Penulisan Naskah Multimedia. Makalah disjaikan dalam Seminar Multimedia di Bandungan Semarang 12 Agustus 2004 (tidak diterbitkan)

Uno, HB. 2009. Model Pembelajaran Menciptakan Proses Belajar Mengajar yang Kreatif dan Efektif. Jakarta : Bumi Aksara.

Wahyu, 2004. Model Pengelolaan Sumber Belajar dan 
Andri Wirawan / Komunitas 2 (2) (2010) : 164-173

Media Pembelajaran Guru Tingkat SMA se-Jawa Tengah. Dinas Pendidikan Nasional Prop. Jateng (tidak diterbitkan).
Wena, M. 2009. Strategi Pembelajaran Inovatif Kontemporer. Jakarta : Bumi Aksara. 